\title{
Growth, yield, water and effluent quality in ponds with different management during tambaqui juvenile production
}

\author{
Ana Maria Dias da Silva(1), Levy de Carvalho Gomes ${ }^{(2)}$ and Rodrigo Roubach ${ }^{(1)}$
}

(1)Instituto Nacional de Pesquisas da Amazônia, Caixa Postal 478, CEP 69011-970 Manaus, AM, Brazil. E-mail: anadias17@hotmail.com, roubach@inpa.gov.br (2)Embrapa Amazônia Ocidental, Caixa Postal 319, CEP 69010-970 Manaus, AM, Brazil. E-mail: levy@cpaa.embrapa.br

\begin{abstract}
The objective of this work was to evaluate the effect of pond management on fish feed, growth, yield, survival, and water and effluent quality, during tambaqui (Colossoma macropomum) juvenile production. Fish were distributed in nine $600 \mathrm{~m}^{2}$ earthen ponds, at a density of 8 fish per $\mathrm{m}^{2}$; the rearing period was 60 days. Three different pond management were applied: limed and fertilized (LimFer), limed (Lim), and natural (Nat). Fish were fed with a commercial ration containing $34 \%$ crude protein three times daily. There were no significant differences in fish growth or yield. Three main items found in tambaqui stomach were insect, zooplankton and ration, without a significant difference among treatments in proportion. Alkalinity, hardness, and $\mathrm{CO}_{2}$ were greater in LimFer and Lim ponds. Chlorophyll $a$, transparency, ammonia, nitrite, temperature, and dissolved oxygen of pond water were not significantly different among treatments. Biochemical oxygen demand, total phosphorus, orthophosphate, ammonia, and nitrite were significantly greater in effluents from LimFer ponds. Pond fertilization should be avoided, because growth and yield were similar among the three pond management systems tested; besides, it produces a more impacting effluent.
\end{abstract}

Index terms: Colossoma macropomum, growth, yield, diet, environmental impact.

\section{Crescimento, produção e qualidade da água e do efluente em viveiro de tambaqui com diferentes manejos durante a recria}

\begin{abstract}
Resumo - O objetivo deste trabalho foi avaliar o efeito do manejo de viveiro sobre a alimentação, crescimento, produtividade, sobrevivência, qualidade da água e do efluente, durante a recria do tambaqui (Colossoma macropoтит). Os peixes foram distribuídos em nove viveiros de $600 \mathrm{~m}^{2}$, à densidade de 8 peixes por $\mathrm{m}^{2}$, e criados por 60 dias. Foram aplicados três diferentes manejos de viveiro: com calagem e fertilizante (LimFer), com calagem (Lim) e natural (Nat). Os peixes foram alimentados três vezes ao dia, com ração comercial com $34 \%$ de proteína bruta. Não houve diferença significativa no crescimento e na produtividade. Os três principais itens encontrados no estômago do tambaqui foram inseto, zooplâncton e ração. Não houve diferença significativa na proporção desses itens entre os tratamentos. Alcalinidade, dureza e $\mathrm{CO}_{2}$ foram maiores nos viveiros LimFer e Lim. Clorofila $a$, transparência, amônia, nitrito, temperatura e oxigênio dissolvido da água dos viveiros não apresentaram diferenças significativas entre os tratamentos. Demanda bioquímica de oxigênio, fósforo total, ortofosfato, amônia e nitrito foram significativamente maiores nos efluentes do tratamento LimFer. A fertilização dos viveiros deve ser evitada, pois o crescimento e a produtividade foram similares entre os manejos testados; além disso, a fertilização produz um efluente mais impactante.
\end{abstract}

Termos para indexação: Colossoma macropomum, crescimento, produtividade, alimentação, impacto ambiental.

\section{Introduction}

Pond management is a common aquaculture practice which has a direct impact on effluent quality (Boyd et al., 2000). Well-managed ponds tend to have a better water and effluent quality. It is performed for several reasons: pond drying for soil aeration (Boyd \& TeichertCoddington, 1992), liming to increase water $\mathrm{pH}$, hardness, and alkalinity to adequate concentrations for fish production (Queiroz et al., 2004) and periodic fertilization to increase plankton production (Boyd \& Tucker, 1998).

There are several established fish production systems, in which pond management is an important phase, for example with tilapia Nilotica Oreochromis niloticus, silver carp Hypophthalmichthys molitrix, common carp Cyprinus carpio (Abdelghany et al., 2002), and 
tambaqui Colossoma macropomum (Melo et al., 2001). Pond management performed for this species involves bottom exposure to sun, liming and fertilization. These production systems take into consideration an increase in fish production, with low importance to environmental impact. Seo \& Boyd (2001a) evaluated several pond management procedures, performed during channel catfish Ictalurus punctatus production, and found fish production similar in managed and unmanaged ponds. Their results showed that fish production could be maintained even when directed for less pollutant production.

Tambaqui is the main native species raised in Brazil, and also in other South and Central American countries, because it is adaptable to captivity, has good feed conversion, easy juvenile availability, fast growth and easy management (Araujo-Lima \& Goulding, 1997). Tambaqui culture is carried out in three phases: larviculture, juvenile production and grow out phase. Juvenile production lasts 60 days, and its objective is to grow fish from 0.5 to $40-50 \mathrm{~g}$.

The objective of this work was to evaluate the effect of pond management on fish feed, growth, yield, survival, and water and effluent quality during tambaqui (Colossoma macropomum) juvenile production.

\section{Material and Methods}

Tambaqui $(2.81 \pm 0.52 \mathrm{~cm}$ length, and $0.41 \pm 0.25 \mathrm{~g}$ weight) were stocked in nine $600 \mathrm{~m}^{2}$ ponds at a density of 8 fish per $\mathrm{m}^{2}$ (4,800 fish per pond), at Balbina fish hatchery, Presidente Figueiredo, Amazonas, Brazil. Pond water was supplied by Uatumã River and distributed by gravity in channels, and water drainage from the surface was discharged in a monk.

The experiment lasted for 60 days (tambaqui juvenile production phase), with three different pond management, and three replications each: LimFer-limed $\left(4,000 \mathrm{~kg} \mathrm{ha}^{-1}\right.$ $\left.\mathrm{CaMg}\left(\mathrm{CO}_{3}\right)_{2}\right)$ and fertilized ponds $\left(20 \mathrm{~kg} \mathrm{ha}^{-1}\right.$ urea and $60 \mathrm{~kg} \mathrm{ha}^{-1}$ triple superphosphate) (Melo et al., 2001); Lim - limed ponds $\left(4,000 \mathrm{~kg} \mathrm{ha}^{-1} \mathrm{CaMg}\left(\mathrm{CO}_{3}\right)_{2}\right)$, the most used procedure by Amazonian fish farmers; Nat - ponds supplied with water, referred to as natural ponds. Daily water exchange was performed at a rate of $1 \%$ in all ponds. Fertilization and limation were done just one time, at the start of the experiment.

Fish were daily fed at $10 \%$ of biomass divided in 3 meals $(8,13$ and $17 \mathrm{~h})$ with a $3 \mathrm{~mm}$ and $34 \%$ crude protein commercially extruded ration.
Fish stomachs were collected to evaluate tambaqui feeding content during the experiment. Ten fish, from each pond, were collected $30 \mathrm{~min}$ after feeding. Fish samplings were taken every 15 days, with the first sample taken 6 days after the start of the experiment, and the others after 21, 36 and 51 days. Fishes were sacrificed, their stomach were removed and kept in $4 \%$ formalin for further analysis of their contents. Stomach contents were quantified by feed items presence and percentage of each item in the overall stomach content. Using the frequency of occurrence (FO) method, and deriving qualitative information about the species diet (Zavala-Camin, 1996), three categories were established: ration, insects and zooplankton. A visual analysis with a stereomicroscope was performed, to establish the percentage of each item in relation to the total stomach content, followed by the quantification of each single item.

Seventy fish, from each pond, were collected after 30 and 60 days to determine fish growth and yield. Fish were anesthethized with benzocaine $\left(100 \mathrm{mg} \mathrm{L}^{-1}\right)$, weighted and measured. Biometrical results were used to calculate growth as fish coefficient of variation $[\mathrm{CV}=100$ (length standard deviation/mean length) $]$ and specific growth rate $(\mathrm{SGR}=100[$ (ln final weight ln initial weight)/time]). After 60 days, the following productivity parameters were analyzed: percentage of fish survival, apparent feed conversion $(\mathrm{AFC}=$ feed consumption/weight gain), yield per area (fish per $\mathrm{m}^{2}$ ), and weight gain ( $\mathrm{WG}=$ final weight - initial weight $)$.

Pond water quality and water from the inlet water channel were daily monitored at $7 \mathrm{~h}$ for oxygen $\left(\mathrm{mg} \mathrm{L}^{-1}\right)$ and temperature $\left({ }^{\circ} \mathrm{C}\right)$, with a digital oxygen meter, and every 7 days for $\mathrm{pH}$ with a digital potentiometer, water hardness and alkalinity by titration, transparency with a Secchi disk, ammonia by the phenol method and nitrite by the sulfanilamide method. Carbon dioxide was analyzed by titration with $\mathrm{NaOH}$. Water was collected from the middle of the pond at $80 \mathrm{~cm}$ depth.

For effluent analysis, exchanged water was collected every 7 days at the pond monk. Measured variables were: biochemical oxygen demand (BOD), using the standard 5-day BOD; total ammonia, using the phenol method; orthophosphate and total phosphorous, by colorimetry. Total solids in suspension (TSS) were measured from the filtered residue weight in a $1 \mu \mathrm{m}$ fiber glass filter. Settleable matter was measured in an Imhoff cone; and chlorophyll $a$ was evaluated using the extraction method with acetone/methanol and 
spectrophotometer reading. Chemical oxygen demand was measured by the "heat-of-dilution" dichromate oxidation method (Boyd, 1979). All procedures for water and effluent sampling, preservation and analytical determinations were made according to the Standard Methods of the American Public Health Association (1992).

Feeding, water quality and effluents data were all tested for normal distribution and variance homogeneity and an ANOVA time-repeated were performed. Means were compared by Tukey test, at $5 \%$ of probability. Growth and yield results were evaluated with ANOVA, and means were compared by Tukey test, at $5 \%$ of probability.

\section{Results and Discussion}

Feed management is one of the most important factors in fish culture (Mihelakakis et al., 2002) and is responsible for production optimization. In the present work, it was observed that zooplankton and insects were consumed throughout the experimental period, with higher intensity at the initial days (Figure 1). Ration consumption was more intensive after 21 days. Ration contribution on tambaqui diet increased $(\mathrm{p}<0.05)$ during the grow out period for all treatments. Insect contribution significantly decreased $(\mathrm{p}<0.05)$, and zooplankton contribution was continuous ( $p>0.05)$. All values for the diets items were identical, and there were no differences among treatments nor statistical significance of the interaction treatment $\mathrm{x}$ time for this growth phase with tambaqui. Fish stomachs were full in all sampling periods, demonstrating abundant food during the whole production cycle. Stomach content analysis showed that with longer experimental period fish became more selective, minimizing zooplankton and insect consumption, and ration was the main diet item. After 6 days, commercial ration in the experimental ponds contributed with $30 \%$ of the fish diet. After 21 days, fish had commercial ration as its main diet item. At the end, commercial ration was responsible for more than $80 \%$ of the juvenile tambaqui stomach content. Therefore using a commercial ration from the start is an adequate feed management procedure, during tambaqui juvenile production.

Primary production indicators (transparency and chlorophyll $a$ ) showed that production was similar among all treatments and constant throughout the experimental period. This result was not expected, because pond fertilization normally increases primary production (Boyd
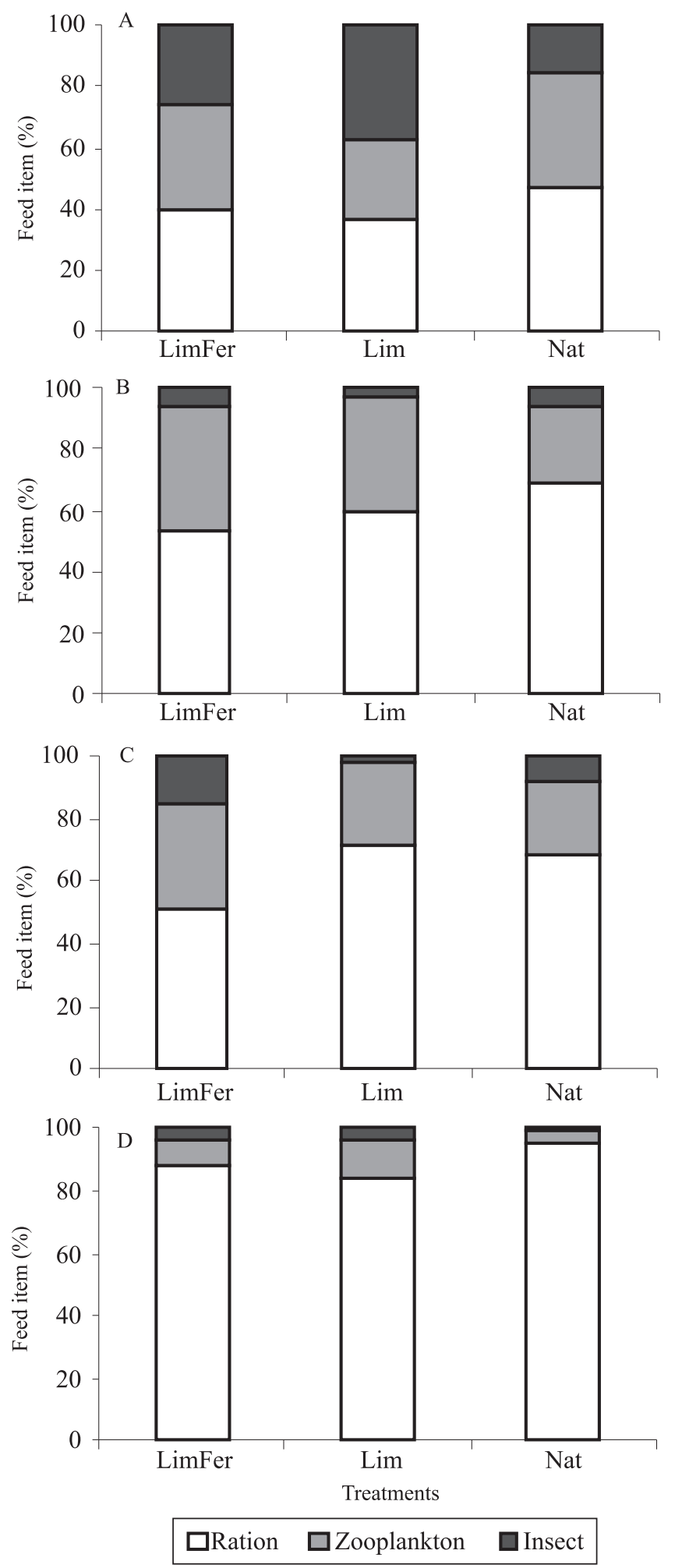

Figure 1. Relative frequency percentage of feed items, during the juvenile tambaqui production in ponds, after 6 (A), 21 (B), 36 (C) and 51 (D) days. LimFer: limed and fertilized ponds. Lim: limed ponds. Nat: natural ponds. 
\& Tucker, 1998). The results showed that feed variation and feed ingested proportion are not influenced by pond management but by rearing period.

Although commercial ration was the main alimentary item during tambaqui juvenile production, the importance of natural feed for this phase was evident by the large contribution of natural food in the stomach content. Similar findings were reported by Zaniboni-Filho (1992), when zooplankton and commercial ration corresponded to more than half of the alimentary items in tambaqui larvae.

Fish growth was homogeneous at 30 and 60 days, without differences in the coefficient of variation $(p>0.05)$, specific growth rate $(p>0.05)$, fish length ( $p>0.05)$, and weight ( $p>0.05)$, among pond management techniques (Table 1). Final mean weight and length were similar to values described by Melo et al. (2001) for tambaqui juvenile production in ponds, and greater than the ones observed in cages, which were $20 \mathrm{~g}$ and $10.5 \mathrm{~cm}$ (Brandão et al., 2004).

Specific growth rate was similar for all treatments, after 30 and 60 days of rearing. Gomes et al. (2004) observed 10\% SGR in the initial 30 days, and $5.6 \%$ for the last 30 days with tambaqui juvenile in cages. In the present work, SGR varied between 10.9 and $11.2 \%$ after 30 days of rearing, and 7.61 and $7.86 \%$ in the last 30 days, showing that tambaqui, during this growth phase, presented better growth potential when reared in ponds

Table 1. Growth of tambaqui, during the juvenile production, with different pond management ${ }^{(1)}$.

\begin{tabular}{lcc}
\hline Treatment & \multicolumn{2}{c}{ Rearing period (days) } \\
\cline { 2 - 3 } & \multicolumn{2}{c}{ Lenght $(\mathrm{cm})$} \\
LimFer & $8.77 \pm 0.76 \mathrm{a}$ & $14.27 \pm 1.04 \mathrm{a}$ \\
Lim & $8.57 \pm 0.78 \mathrm{a}$ & $13.61 \pm 0.88 \mathrm{a}$ \\
Nat & $9.19 \pm 0.64 \mathrm{a}$ & $13.52 \pm 0.95 \mathrm{a}$ \\
\hline & $11.94 \pm 3.14 \mathrm{a}$ & Weight $(\mathrm{g})$ \\
LimFer & $10.97 \pm 2.43 \mathrm{a}$ & $46.47 \pm 1.40 \mathrm{a}$ \\
Lim & $11.07 \pm 2.5 \mathrm{a}$ & $39.97 \pm 0.88 \mathrm{a}$ \\
Nat & Coefficient of variation of fish length $(\%)$ \\
& $8.64 \pm 1.4 \mathrm{a}$ & $7.26 \pm 0.21 \mathrm{a}$ \\
LimFer & $9.13 \pm 0.48 \mathrm{a}$ & $6.47 \pm 0.16 \mathrm{a}$ \\
Lim & $6.96 \pm 0.31 \mathrm{a}$ & $7.03 \pm 0.16 \mathrm{a}$ \\
Nat & \multicolumn{1}{c}{ Specific growth rate $(\%)$} \\
\hline & $11.19 \pm 0.49 \mathrm{a}$ & $7.86 \pm 0.84 \mathrm{a}$ \\
LimFer & $10.91 \pm 0.44 \mathrm{a}$ & $7.61 \pm 0.21 \mathrm{a}$ \\
Lim & $10.94 \pm 0.97 \mathrm{a}$ & $7.69 \pm 0.21 \mathrm{a}$ \\
Nat & \multicolumn{2}{c}{ (1)LimFer: limed and fertilized ponds; Lim: limed ponds; Nat: natural } \\
ponds; mean \pm SE from three replications from each pond treatment; \\
means in each line, followed by different letters, are significantly different \\
by Tukey's test, at 5\% of probability.
\end{tabular}

than in cages. Coefficient of variation was similar among treatments, lower than $10 \%$, showing that fish growth was homogeneous (Jobling, 1994).

There were no differences among treatments related to fish survival, WG, AFC, and yield (Table 2). $\mathrm{AFC}$ was similar to the one found for tambaqui in cages, 0.7-1.27, during juvenile production (Brandão et al., 2004; Gomes et al., 2004) and grow out phase in ponds (1.3) (Jiménez-Montealegre et al., 2005). Matrinxã juveniles (Brycon amazonicus) also had AFC around 1.3, during the same growth phase (Brandão et al., 2005), showing that AFC was within the expected range for this and other tropical fish species.

Fish yield was smaller than the one reported by Melo et al. (2001), during tambaqui juvenile production, and it was related to a higher stocking density (10 fishes per $\mathrm{m}^{2}$ ), and higher survival (75\%) used by those authors.

The observed mean fish survival (around $48.39 \%$ ) was inferior to the ones described during juvenile production for: Nile tilapia, silver carp, and common carp (Abdelghany et al., 2002), and sunshine bass (Morone saxatilis Walbaum $\mathrm{x}$ M. chrysops) (D'Abramo et al., 2002, 2004).

Pond fertilization did not influence dissolved oxygen. Means varied from 4.86 to $5.38 \mathrm{mg} \mathrm{L}^{-1}$ (Table 3), and were not different among treatments. There was a small decrease in the water oxygen content during the experimental period, reaching its lowest values (around $2 \mathrm{mg} \mathrm{L}^{-1}$ ) during the last days in all treatments, because of the higher oxygen consumption caused by fish biomass increase in the ponds. Similar oxygen pattern ocurred during tambaqui grow out period (Teichert-Coddington, 1996), and during matrinxã larviculture in ponds (Gomes et al., 2000).

Table 2. Percentage of survival, weight gain, apparent feed conversion (AFC) and yield of tambaqui juvenile, with different pond management ${ }^{(1)}$.

\begin{tabular}{lcccc}
\hline Treatment & $\begin{array}{c}\text { Survival } \\
(\%)\end{array}$ & $\begin{array}{c}\text { Weight gain } \\
(\mathrm{g})\end{array}$ & AFC & $\begin{array}{c}\text { Yield } \\
\left(\text { fish m }^{-2}\right)\end{array}$ \\
\hline LimFer & $47.58 \pm 3.13 \mathrm{a}$ & $46.06 \pm 0.45 \mathrm{a}$ & $1.20 \pm 0.06 \mathrm{a}$ & $3.81 \pm 0.25 \mathrm{a}$ \\
Lim & $49.06 \pm 1.69 \mathrm{a}$ & $39.55 \pm 0.45 \mathrm{a}$ & $1.07 \pm 0.45 \mathrm{a}$ & $3.93 \pm 0.14 \mathrm{a}$ \\
Nat & $48.53 \pm 7.03 \mathrm{a}$ & $41.35 \pm 1.62 \mathrm{a}$ & $1.30 \pm 0.18 \mathrm{a}$ & $3.88 \pm 0.56 \mathrm{a}$ \\
\hline
\end{tabular}

(1)LimFer: limed and fertilized ponds; Lim: limed ponds; Nat: natural ponds; means \pm SE from three replications from each pond treatment; means in each column, followed by different letters, are significantly different by Tukey's test, at $5 \%$ of probability. 
Tambaqui is well known for its tolerance to low oxygen concentration (Araujo-Lima \& Goulding, 1997). Despite the low values registered during the last week, there was no apparent fish mortality; however, the growth of fish probably lowered during this period, which is economically undesirable. The dissolved oxygen results suggest the need for pond management with greater water exchange during the last week of juvenile production. Mean water temperature in all ponds varied between 29.87 and $30.22^{\circ} \mathrm{C}$ (Table 3), which is the appropriate temperature range to raise Amazon fishes (Saint-Paul, 1986).

The $\mathrm{pH}$ was significantly higher in LimFer and Lim, than in Nat treatment (Table 3), showing that pond liming was efficient to increase water $\mathrm{pH}$, but not fish yield. Liming is an usual procedure in some Amazon fish farms (Aride et al., 2004). However, wild tambaqui is known to live in acidic waters, with low concentrations of dissolved salts, as the ones of the Uatumã River. According to Aride et al. (2004), acid water does not have a negative impact on tambaqui yield, affirmation supported by the present work, where fish raised in Nat treatment presented a growth similar to fish from other pond management. The values of $\mathrm{pH}$ in the Nat treatment are slightly acidic and similar to the ones obtained in the inlet water channel.

Alkalinity and hardness were significantly higher in LimFer and Lim treatments. These treatments presented alkalinity and hardness mean values above $20 \mathrm{mg} \mathrm{L}^{-1}$, as the result of liming achieved, which are within the range of ideal values for fish rearing according to Boyd $\&$ Tucker (1998). Ponds from Nat treatment presented lower values, around $20 \mathrm{mg} \mathrm{L}^{-1}$. Queiroz et al. (2004) demonstrated that liming increases pond water alkalinity and hardness, besides it corrects water $\mathrm{pH}$, and is beneficial to fish yield. In the present work, it was observed a similar effect on the water alkalinity and hardness increase, however pond liming did not increase fish yield. These results suggest that liming is a dispensable procedure during tambaqui juvenile production in Amazon.

According to Chagas et al. (2003), very high ammonia concentrations can be harmful for fish growth performance. Mean observed values were from 0.24 to $0.36 \mathrm{mg} \mathrm{L}^{-1}$ (Table 3), which is in the fish comfort zone (Boyd \& Tucker, 1998). Sipaúba-Tavares et al. (1999) found lower ammonia values $\left(0.07-0.180 \mathrm{mg} \mathrm{L}^{-1}\right)$ than the ones in the present work, in experiments with pacu, Piaractus mesopotamicus, probably due to the lower biomass. With higher biomass, Seok et al. (1995) found ammonia values between 0.47 and $1.11 \mathrm{mg} \mathrm{L}^{-1}$ in channel catfish. Mean nitrite values were below to the critical values $\left(1.82 \pm 0.98 \mathrm{mg} \mathrm{L}^{-1}\right)$ previously described for the species (Costa et al., 2004).

Carbon dioxide values higher than $25 \mathrm{mg} \mathrm{L}^{-1}$ can affect fish growth performance, and even suffocate fish; therefore, ideal concentrations should be lower than $5 \mathrm{mg} \mathrm{L}^{-1}$ (Boyd \& Tucker, 1998). Carbon dioxide mean value around $2.3 \mathrm{mg} \mathrm{L}^{-1}$ was observed (Table 3 ), which is appropriate and below to critical range for pond fish culture.

Effluent studies for tambaqui juvenile production system are rare. The importance of environment impact assessment imposed by the activity is unquestionable (Boyd, 2003); therefore, this work is a start point for this assessment, quantification, and future recommendations for best management practice (BMP's) for tambaqui rearing.

Mean biochemical oxygen demands (BOD) in the effluent were 5.61, 4.28 and $4.59 \mathrm{mg} \mathrm{L}^{-1}$, for treatments

Table 3. Water quality parameters, during tambaqui juvenile production, with different pond management ${ }^{(1)}$.

\begin{tabular}{|c|c|c|c|c|}
\hline Parameters & Channel $^{(2)}$ & LimFer & Lim & Nat \\
\hline Dissolved oxygen $\left(\mathrm{mg} \mathrm{L}^{-1}\right)$ & $4.86 \pm 0.55$ & $5.22 \pm 1.25 \mathrm{a}$ & $5.38 \pm 0.76 a$ & $4.95 \pm 0.94 a$ \\
\hline Temperature $\left({ }^{\circ} \mathrm{C}\right)$ & $29.95 \pm 0.40$ & $29.87 \pm 1.22 \mathrm{a}$ & $30.13 \pm 0.56 \mathrm{a}$ & $30.22 \pm 0.73 a$ \\
\hline Carbon dioxide $\left(\mathrm{mg} \mathrm{L}^{-1}\right)$ & $1.79 \pm 0.23$ & $2.17 \pm 0.94 b$ & $1.94 \pm 0.70 b$ & $2.79 \pm 0.93 \mathrm{a}$ \\
\hline $\mathrm{pH}$ & $6.52 \pm 0.27$ & $7.35 \pm 0.36 \mathrm{a}$ & $7.33 \pm 0.33 \mathrm{a}$ & $6.78 \pm 0.23 b$ \\
\hline Total alkalinity $\left(\mathrm{mg} \mathrm{L}^{-1}\right)$ & $8.31 \pm 2.75$ & $26.91 \pm 3.76 \mathrm{a}$ & $22.15 \pm 5.26 \mathrm{a}$ & $17.12 \pm 4.78 b$ \\
\hline Total hardness $\left(\mathrm{mg} \mathrm{L}^{-1}\right)$ & $9.01 \pm 7.08$ & $23.56 \pm 3.54 \mathrm{a}$ & $19.09 \pm 5.98 \mathrm{a}$ & $13.11 \pm 2.46 \mathrm{~b}$ \\
\hline Total ammonia $\left(\mathrm{mg} \mathrm{L}^{-1}\right)$ & $0.24 \pm 0.18$ & $0.36 \pm 0.17 \mathrm{a}$ & $0.26 \pm 0.18 \mathrm{a}$ & $0.27 \pm 0.23 \mathrm{a}$ \\
\hline Nitrite $\left(\mathrm{mg} \mathrm{L}^{-1}\right)$ & $0.005 \pm 0.003$ & $0.009 \pm 0.005 \mathrm{a}$ & $0.005 \pm 0.003 b$ & $0.005 \pm 0.003 b$ \\
\hline Secchi disk visibility $(\mathrm{cm})$ & - & $53.44 \pm 19.87 \mathrm{a}$ & $75.56 \pm 20.47 a$ & $79.81 \pm 19.62 \mathrm{a}$ \\
\hline
\end{tabular}

(1)LimFer: limed and fertilized ponds; Lim: limed ponds; Nat: natural ponds; means \pm SE from three repetitions from each pond treatment; means in each line, followed by different letters, are significantly different by Tukey's test, at $5 \%$ of probability. ${ }^{(2)} \mathrm{Channel}$ : water from inlet water channel. 
LimFer, Lim and Nat (Table 4), respectively, and were similar to the ones observed $\left(9 \mathrm{mg} \mathrm{L}^{-1}\right)$ for baitfish Notemigonus crysoleucas (Bodary et al., 2004) and channel catfish ponds (Boyd \& Gross, 1999). Chemical oxygen demand (COD) was used as an index of organic matter concentration and to estimate oxygen consumption by planktonic communities (Boyd, 1979). Mean values around $9.3 \mathrm{mg} \mathrm{L}^{-1}$ were found, which are low, when compared to ponds with channel catfish (Seo \& Boyd, 2001a). LimFer ponds presented a higher chemical oxygen demand, possibly due to the fertilization.

Total phosphorus concentration in the effluent was higher in LimFer ponds than in other pond managements (Table 4), as a result of phosphorus input in triple superphosphate. Teichert-Coddington (1996) found values around $1.56 \mathrm{mg} \mathrm{L}^{-1}$, during tambaqui grow out experiment, associated to a higher fertilizer quantity and frequency than the ones used in the present study. In channel catfish ponds, total phosphorus reached values between 0.34 and $1.21 \mathrm{mg} \mathrm{L}^{-1}$ (Seok et al., 1995; Seo \& Boyd, 2001b); and for baitfish, the mean concentration was $0.5 \mathrm{mg} \mathrm{L}^{-1}$ (Bodary et al., 2004). Phosphorus discharge, during tambaqui juvenile production, was similar to the observed for several species.

Melo et al. (2001) reported values of up to $1 \mathrm{mg} \mathrm{L}^{-1}$ total ammonia on the effluents, during tambaqui growth period; in the present work, the values were well below and probably related to a lower biomass during the study. Higher ammonia concentration found in the effluents of the LimFer reflected the addition of nitrogen sources, as urea and triple superphosphate. Nitrite means showed no significant differences. Results demonstrate that nitrogen discharge, during tambaqui juvenile production, is probably not harmful to the environment, mainly in the Nat treatment.

Settleable matter and TSS showed no significant differences ( $p>0.05$ ) among treatments (Table 4). Boyd et al. (2000) described values of $540 \mathrm{mg} \mathrm{L}^{-1}$ for channel catfish, and pointed out TSS as one of the main pollutant in channel catfish ponds, which were not observed in the present work, where TSS were around 100 times lower. Mean values for settleable matter varied between 0.01 and $0.02 \mathrm{mg} \mathrm{L}^{-1}$ among treatments.

Pond fertilization had the objective, among others, to increase the primary production, but contrary to the expected results, fertilization performed in ponds from treatment LimFer did not cause a significant increase in chlorophyll $a$ (Table 4). These values were higher than the ones obtained (5.1 to $8.7 \mu \mathrm{g} \mathrm{L}^{-1}$ ) in pacu ponds (Sipaúba-Tavares et al., 1999), and lower than the ones obtained during tambaqui grow out in highly fertilized ponds $\left(296 \mu \mathrm{g} \mathrm{L}^{-1}\right)$ (Teichert-Coddington, 1996). The results show that fertilization is an unnecessary procedure, mainly in ponds that receive fish ration.

Boyd et al. (2000) and Boyd (2003) evaluated the concentrations of several parameters from channel catfish ponds drained water, and most of the values were not potentially pollutant; only total phosphorus concentration and TSS indicated a potential pollutant problem for receiving water bodies. Among data obtained in this study, only phosphorus presented elevated values.

Results showed that liming and fertilization should be avoided, because it is possible to keep an appropriate yield without its addition. Besides, as fertilization and liming are around $4.5 \%$ of operational costs (Melo et al., 2001), tambaqui production will be less expensive without those additives.

Table 4. Effluent quality parameters, during juvenile tambaqui production, with different pond management ${ }^{(1)}$.

\begin{tabular}{llcc}
\hline Parameter & Channel & LimFer & Nat \\
\hline Chemical oxygen demand $\left(\mathrm{mg} \mathrm{L}^{-1}\right)$ & $5.08 \pm 1.85$ & $12.0 \pm 4.59 \mathrm{a}$ & $7.77 \pm 1.92 \mathrm{~b}$ \\
Biochemical oxygen demand $\left(\mathrm{mg} \mathrm{L}^{-1}\right)$ & $3.87 \pm 1.87$ & $5.61 \pm 1.33 \mathrm{a}$ & $4.28 \pm 0.88 \mathrm{a}$ \\
Total suspended solids $\left(\mathrm{mg} \mathrm{L}^{-1}\right)$ & $0.20 \pm 0.11$ & $0.41 \pm 0.11 \mathrm{a}$ & $0.61 \pm 0.20 \mathrm{a}$ \\
Settleable matter $\left(\mathrm{mg} \mathrm{L}^{-1}\right)$ & $0.01 \pm 0.01$ & $0.02 \pm 0.03 \mathrm{a}$ & $0.02 \pm 0.03 \mathrm{a}$ \\
Total phosphorus $\left(\mathrm{mg} \mathrm{L}^{-1}\right)$ & $0.03 \pm 0.04$ & $0.54 \pm 0.35 \mathrm{a}$ & $0.22 \pm 0.09 \mathrm{~b}$ \\
Orthophosphate $\left(\mathrm{mg} \mathrm{L}^{-1}\right)$ & $0.01 \pm 0.005$ & $0.47 \pm 0.25 \mathrm{a}$ & $0.15 \pm 0.04 \mathrm{~b}$ \\
Total ammonia $\left(\mathrm{mg} \mathrm{L}^{-1}\right)$ & $0.24 \pm 0.18$ & $0.40 \pm 0.22 \mathrm{a}$ & $0.30 \pm 0.22 \mathrm{~b}$ \\
Nitrite $\left(\mathrm{mg} \mathrm{L}^{-1}\right)$ & $0.005 \pm 0.003$ & $0.01 \pm 0.007 \mathrm{a}$ & $0.01 \pm 0.01 \mathrm{a}$ \\
Chlorophyll $a\left(\mu \mathrm{g} \mathrm{L}^{-1}\right)$ & $6.57 \pm 3.16$ & $23.08 \pm 12.0 \mathrm{a}$ & $0.23 \pm 0.07 \mathrm{~b}$ \\
\hline
\end{tabular}

(1)LimFer: limed and fertilized ponds; Lim: limed ponds; Nat: natural ponds; means \pm SE from three replications from each pond treatment; means in each line, followed by different letters, are significantly different by Tukey's test, at $5 \%$ of probability. ${ }^{(2)}$ Channel: water from inlet water channel. 


\section{Conclusions}

1. Pond management does not affect food intake, growth and yield of Colossoma macropomum juvenile.

2. Fertilization and liming procedures increase the environmental impact of the activity.

3. Phosphorus concentration in the effluent is the only water quality parameter with potential impact to the environment, during tambaqui juvenile production.

4. Juvenile tambaqui production in the Amazon should be performed in ponds without liming and fertilization.

\section{Acknowledgments}

To Embrapa Amazônia Ocidental staff members: Márcia Pessoa, Marcus Brito and Clichenner Silva, for help in water and effluents analysis; to Sepa/Sepror, for allowing the use of ponds at Balbina fish culture station; to the International Foundation for Science (IFS), for financial support; to Fundação de Amparo à Pesquisa do Estado do Amazonas (Fapeam), for the scholarship to the first author; to Conselho Nacional de Desenvolvimento Científico e Tecnológico (CNPq), for the research fellowship to the second and third author.

\section{References}

ABDELGHANY, A.E.; AYYAT, M.S.; AHMAD, M.H. Appropriate timing of supplemental feeding for production of Nile tilapia, silver carp, and common carp in fertilized polyculture ponds. Journal of the World Aquaculture Society, v.33, p.307-315, 2002.

AMERICAN PUBLIC HEALTH ASSOCIATION. Standard methods for the examination of water and wastewater. $18^{\text {th }} \mathrm{ed}$. New York, 1992. 1220p.

ARAUJO-LIMA, C.A.R.M.; GOULDING, M. So fruitful fish: ecology, conservation, and aquaculture of the Amazon's tambaqui. New York: Columbia University Press, 1997. 157p.

ARIDE, P.H.R.; ROUBACH, R.; VAL, A.L. Water pH in central Amazon and its importance for tambaqui (Colossoma macropomum) culture. World Aquaculture, v.35, p.24-27, 2004.

BODARY, M.J.; STONE, N.; LOCHMANN, S.E.; FRIMPONG, E. Characteristics of effluents from central Arkansas baitfish ponds. Journal of the World Aquaculture Society, v.35, p.489497, 2004.

BOYD, C.E. Determination of total ammonia nitrogen and chemical oxygen demand in fish culture systems. Transactions of the American Fisheries Society, v.108, p.304-319, 1979.

BOYD, C.E. Guidelines for aquaculture effluents management at the farm-level. Aquaculture, v.226, p.101-112, 2003.

BOYD, C.E.; GROSS, A. Biochemical oxygen demand in channel catfish Ictalurus punctatus pond water. Journal of the World Aquaculture Society, v.30, p.349-356, 1999.
BOYD, C.E.; QUEIROZ, J.F.; LEE, J.Y.; ROWAN, M.; WHITIS, G.N.; GROSS, A. Environmental assessment of channel catfish Ictalurus punctatus farming in Alabama. Journal of the World Aquaculture Society, v.31, p.511-544, 2000.

BOYD, C.E.; TEICHERT-CODDINGTON, D. Relationship between wind speed and reaeration in small aquaculture ponds. Aquacultural Engineering, v.11, p.121-131, 1992.

BOYD, C.E.; TUCKER, C.S. Pond aquaculture water quality management. Boston: Kluwer Academic Publishers, 1998. 700p.

BRANDÃO, F.R.; GOMES, L.C.; CHAGAS, E.C.; ARAÚJO, L.D. Densidade de estocagem de juvenis de tambaqui durante a recria em tanques-rede. Pesquisa Agropecuária Brasileira, v.39, p.357-362, 2004.

BRANDÃO, F.R.; GOMES, L.C.; CHAGAS, E.C.; ARAÚJO, L.D.; SILVA, A.L.F. da. Densidade de estocagem de matrinxã (Brycon amazonicus) na recria em tanque-rede. Pesquisa Agropecuária Brasileira, v.40, p.299-303, 2005.

CHAGAS, E.C.; LOURENÇO, J.N.P.; GOMES, L.C.; VAL, A.L. Desempenho e estado de saúde de tambaquis cultivados em tanquesrede sob diferentes densidades de estocagem. In: SIMPÓSIO BRASILEIRO DE AQÜICULTURA, 12., 2003, Goiânia. Anais. Jaboticabal: Aquabio, 2003. p.83-93.

COSTA, O.T.F.; FERREIRA, D.J.S.; MENDONÇA, F.L.P.; FERNANDES, M.N. Susceptibility of the Amazonian fish, Colossoma macropomum (Serrasalminae), to short-term exposure to nitrite. Aquaculture, v.232, p.627-636, 2004.

D’ABRAMO, L.R.; OHS, C.L.; HANSON, T.R. Effect of stocking weight and stocking density on production of hybrid striped bass (Sunshine) in earthen ponds in the second phase of a 2-phase system. Journal of the World Aquaculture Society, v.35, p.33-45, 2004.

D'ABRAMO, L.R.; OHS, C.L.; HANSON, T.R.; TAYLOR, J.B. Production and economic analysis of two-phase and three-phase culture of sunshine bass in earthen ponds. North American Journal of Aquaculture, v.64, p.103-112, 2002.

GOMES, L.C.; BALDISSEROTTO, B.; SENHORINE, J.A. Effect of stocking density on water quality, survival and growth of larvae of the matrinxã, Brycon cephalus (Characidae) in ponds. Aquaculture, v.183, p.73-81, 2000.

GOMES, L.C.; BRANDÃO, F.R.; CHAGAS, E.C.; FERREIRA, M.F.B.; LOURENÇO, J.N.P. Efeito do tanque-rede na produtividade de tambaqui (Colossoma macropomum) durante a recria. Acta Amazonica, v.34, p.111-113, 2004.

JIMENÉZ-MONTEALEGRE, R.; AVNIMELECH, Y.; VERRETH, J.A.; VERDEGEM, M.C.J. Nitrogen budget and fluxes in Colossoma macropomum ponds. Aquaculture Research, v.36, p.8-15, 2005.

JOBLING, M. Fish bioenergetics. London: Chapman \& Hall, 1994. $294 \mathrm{p}$.

MELO, L.A.S.; IZEL, A.C.U.; RODRIGUES, F.M. Criação de tambaqui (Colossoma macropomum) em viveiros de argila/ barragens no Estado do Amazonas. Manaus: Embrapa Amazônia Ocidental, 2001. 21p. (Documentos, 18).

MIHELAKAKIS, A.; TSOLKAS, C.; YOSHIMATSU, T. Optimization of feeding rate for hatchery-produced juvenile gilthead 
sea bream Sparus aurata. Journal of the World Aquaculture Society, v.33, p.169-175, 2002.

QUEIROZ, J.F.; NICOLELLA, G.; WOOD, C.W.; BOYD, C.E. Lime application methods, water and bottom soil acidity in fresh water fish ponds. Scientia Agricola, v.61, p.469-475, 2004.

SAINT-PAUL, U. Potential for aquaculture of South America freshwater fish: a review. Aquaculture, v.54, p.205-240, 1986.

SEO, J.; BOYD, C.E. Dry-tilling of pond bottoms and calcium sulfate treatment for water quality improvement. Journal of the World Aquaculture Society, v.32, p.257-268, 2001a.

SEO, J.; BOYD, C.E. Effects of bottom soil management practices on water quality improvement in channel catfish Ictalurus punctatus ponds. Aquacultural Engineering, v.25, p.83-97, $2001 \mathrm{~b}$.

SEOK, K.S.; LEONARD, S.; BOYD, C.E.; SCHWARTZ, M. Water quality in annually drained and undrained channel catfish ponds over a tree-year period. Progressive Fish-Culturist, v.57, p.5258, 1995.

SIPAÚBA-TAVARES, L.H.; MORAES, M.A.G.; BRAGA, F.M.S. Dynamics of some limnological characteristics in pacu (Piaractus mesopotamicus) culture tanks as function of handling. Revista Brasileira de Biologia, v.59, p.543-551, 1999.

TEICHERT-CODDINGTON, D.R. Effect of stocking ration on semiintensive polyculture of Colossoma macropomum and Oreochromis niloticus in Honduras, Central America. Aquaculture, v.143, p.291302, 1996.

ZANIBONI-FILHO, E. Incubação, larvicultura e alevinagem do tambaqui (Colossoma macropomum, Cuvier 1818). 1992. 202p. Tese (Doutorado) - Universidade Federal de São Carlos, São Carlos.

ZAVALA-CAMIN, L.A. Introdução ao estudo sobre alimentação natural em peixes. Maringá: Eduem, 1996. 129p.

Received on April 17, 2006 and accepted on March 22, 2007 